\title{
Electrophilic Addition of Polyaromatic o-Quinones to an Iron(II) Diaminoclathrochelate Leading to the Macrobicyclic Iron(II) tris-Dioximates with Extended Annulated Ribbed Substituents
}

\author{
Aleksey B. Burdukov, ${ }^{a}{ }^{@}$ Mikhail A. Vershinin, ${ }^{a}$ Natalie V. Pervukhina, ${ }^{a}$ \\ Nataliya V. Kuratieva, ${ }^{a}$ Ilia V. Eltsov, ${ }^{\text {b }}$ Yan Z. Voloshin, ${ }^{\text {c }}$ and Pavel E. Plyusnin ${ }^{\mathrm{a}, \mathrm{b}}$ \\ ${ }^{a}$ Nikolaev Institute of Inorganic Chemistry SB RAS, 630090 Novosibirsk, Russia \\ ${ }^{\mathrm{b}}$ Novosibirsk State University, 630090 Novosibirsk, Russia \\ 'Nesmeyanov Institute of Organoelement Compounds RAS, 119991 Moscow, Russia \\ @Corresponding authorE-mail: lscc@niic.nsc.ru
}

\begin{abstract}
Macrobicyclic iron(II) tris-dioximate with two inherent amino groups undergoes electrophilic addition with 1,10-phenanthroline-5,6-dione and phenanthrene-9,10-dione to give a cage complexes with extended ribbed substituents. These clathrochelates have been characterized using single crystal XRD, multinuclear NMR and other spectral techniques. They have been found to undergo the ligand-centered redox processes; the obtained phenanthrolinecontaining iron(II) cage complex is proposed as a potent chelating clathrochelate ligand.
\end{abstract}

Keywords: Macrocyclic compounds, clathrochelates, ligand reactivity, electrophilic addition.

\section{Электрофильное присоединение полиароматических о-хинонов к Аиаминоклатрохелату железа(II), приводящее \\ к макробициклическим трис-Аиоксиматам железа(II) с расширенными аннелированными реберными заместителями}
А. Б. Бурдуков, ${ }^{a} @$ М. А. Вершинин, ${ }^{a}{ }^{a}$ И. В. Ельцов, ${ }^{\mathrm{b}}$ Я. З. Волошин, ${ }^{\mathrm{c}}$ П. Е. Плюснинн ${ }^{\mathrm{a}, \mathrm{b}}$
а Институт неорганической химии им. А.В. Николаева СО РАН, 630090 Новосибирск, Россия
${ }^{\mathrm{b}}$ Новосибирский государственный университет, 630090 Новосибирск, Россия
'Институт элементоорганических соединений им. А.Н. Несмеянова, 119991 Москва, Россия
${ }^{\circledR}$ E-mail: lscc@niic.nsc.ru

\begin{abstract}
Трис-диоксиматный клатрохелат железа(II) с двумя амино-группами вступает в реакцию электрофильного присоединения с 1,10-фенантролин-5, 6-дионом и фенантрен-9,10-дионом, приводямую к клеточньм комплексам с расширенными реберными заместителями. Эти клатрохелаты были охарактеризованы методами РСА, мультиядерной ЯМР-спектроскопии и другими спектральными методами. Установлено, что полученные клеточные комплексы претерпевают лиганд-центрированные редокс-процессы; фенантролин-содержаший клеточный комплекс железа(II) предложен в качестве перспективного хелатирующего клатрохелатного лиганда.
\end{abstract}

Ключевые слова: Макроциклические соединения, клатрохелаты, реакционная способность лигандов, электрофильное присоединение. 


\section{Introduction}

Boron-capped metal tris-dioximates (cage complexes, clathrochelates), possessing rather high chemical stability combined with their ability to be functionalized with various substituents, are promising molecular platforms for the design of polytopic multifunctional molecular and supramolecular systems, including those prospective as molecular electronic devices. ${ }^{[1-4]}$ Recently we described an iron(II) clathrochelate with annulated ribbed quinoxaline fragment that exhibited the reversible ligand-centered redox transformations coupled with electrochromism. ${ }^{[5]}$ Its annulated azaheterocyclic moiety has been constructed using nucleophilic substitution of the reactive chlorine atoms in a dichloroclathrochelate precursor $\mathrm{FeBd}_{2}\left(\mathrm{Cl}_{2} \mathrm{Gm}\right)(\mathrm{BF})_{2}$ (where $\mathrm{Bd}^{2-}$ and $\mathrm{Cl}_{2} \mathrm{Gm}^{2-}$ are $\alpha$-benzildioxime and dichloroglyoxime dianions) (Scheme 1).

An alternative pathway to such annulated azaheterocycles is based on the reactions of the appropriate carbonyl compounds as electrophilic agents towards the anionic derivatives of a diaminoclathrochelate $\mathrm{FeBd}_{2}\left(\left(\mathrm{NH}_{2}\right)_{2} \mathrm{Gm}\right)(\mathrm{BF})_{2}$ (where $\mathrm{Gm}$ is glyoxime residue) as a reactive macrobicyclic precursor (Scheme 2) ${ }^{[6]}$

The same synthetic approach (i.e. electrophilic addition) was successfully used to extend the family of the
iron(II) clathrochelates with redox-non-innocent azaheterocylic fragments via condensation of the deprotonated form of this diaminoclathrochelate precursor with polyaromatic $o$-quinones, such as 1,10-phenanthroline-5,6-dione and phenanthrene-9,10-dione. The presence of donor phenanthroline moiety in a clathrochelate molecule allows the synthesis of heterometallic coordination compounds with clathrochelate ligands.

\section{Experimental}

\section{Materials and Methods}

Diaminoclathrochelate $\mathrm{FeBd}\left(\mathrm{Gm}\left(\mathrm{NH}_{2}\right)_{2}\right)(\mathrm{BF})_{2}$ was obtained as described elsewhere. ${ }^{[7]}$ DMSO was dried over $\mathrm{NaOH}$ pellets and distilled in vacuo prior to use. Acetonitrile was purified according to the standard procedure. ${ }^{[8]}$ The commercial reagents, 1,10-phenanthroline-5,6-dione, phenanthrene-9,10-dione and 1,8-diazabicyclo[5.4.0] undecene-7 (DBU) were purchased from Sigma-Aldrich ${ }^{\circledR}$ and used without their further purification. The solution UV-Vis spectra were recorded on a Specord UV-VIS and a Shimadzu UV-3101 PC spectrophotometers. ${ }^{1} \mathrm{H},{ }^{13} \mathrm{C},{ }^{11} \mathrm{~B}$ and ${ }^{19} \mathrm{~F}$ NMR spectra were recorded on a Bruker Avance III 500 spectrometer (working frequencies $500.03\left({ }^{1} \mathrm{H}\right), 125.73\left({ }^{13} \mathrm{C}\right.$ ), $160.33\left({ }^{11} \mathrm{~B}\right)$ and $\left.470.49 \mathrm{MHz}\left({ }^{19} \mathrm{~F}\right)\right)$ in $\mathrm{CDCl}_{3}$ solutions. The ${ }^{1} \mathrm{H}$ and ${ }^{13} \mathrm{C}$ NMR chemical shifts are reported in ppm of the $\delta$ scale

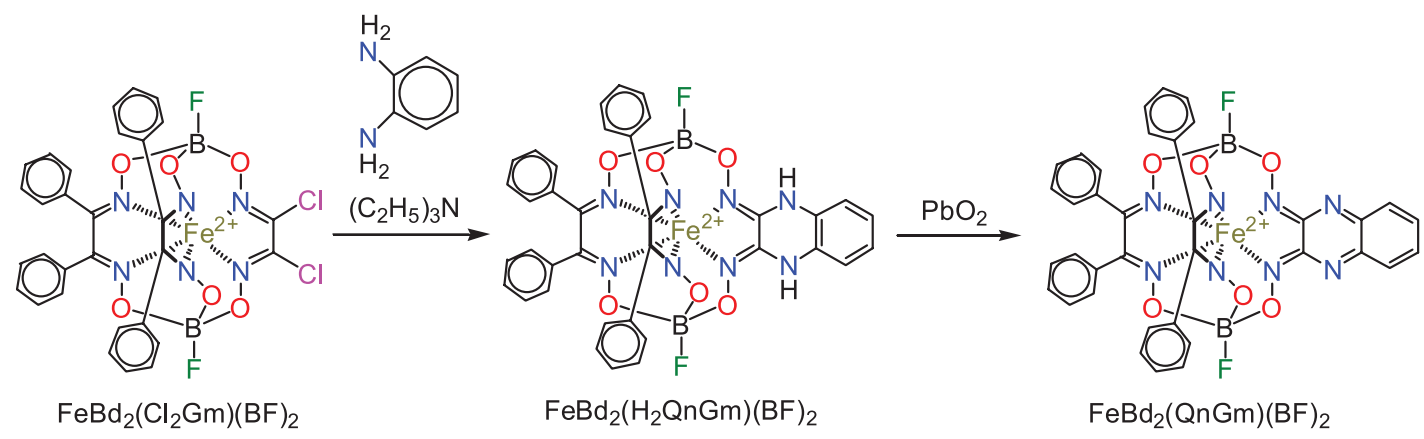

Scheme 1.

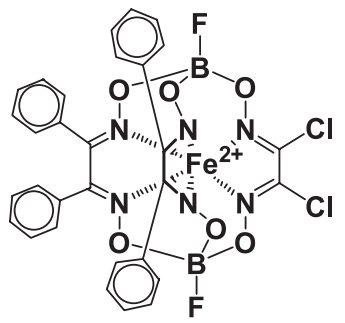

$\mathrm{FeBd}_{2}\left(\mathrm{Cl}_{2} \mathrm{Gm}\right)(\mathrm{BF})_{2}$
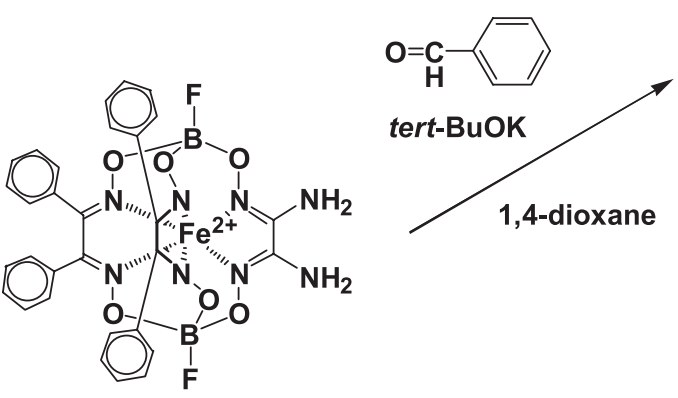

1,4-dioxane

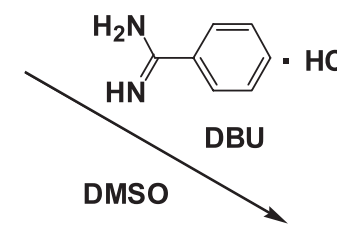

$\mathrm{FeBd}_{2}\left(\left(\mathrm{NH}_{2}\right)_{2} \mathrm{Gm}\right)(\mathrm{BF})_{2}$

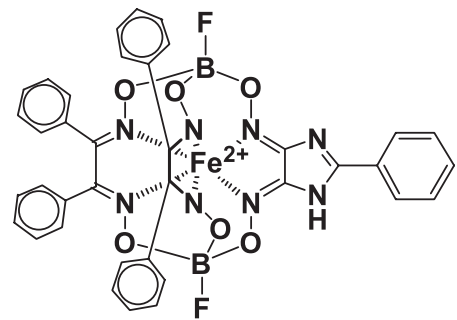

$\mathrm{FeBd}_{2}(\operatorname{Im}(\mathrm{Ph}) \mathrm{Gm})(\mathrm{BF})_{2}$

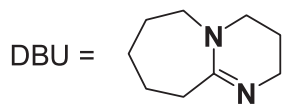


and referred to signals of the solvent (7.26 ppm for residual protons in ${ }^{1} \mathrm{H}$ NMR spectra and $77.23 \mathrm{ppm}$ in ${ }^{13} \mathrm{C}\left\{{ }^{1} \mathrm{H}\right\}$ NMR spectra). ${ }^{11} \mathrm{~B}$ and ${ }^{19} \mathrm{~F}$ NMR chemical shifts are referred to the external standards $\mathrm{BF}_{3} \cdot \mathrm{O}\left(\mathrm{C}_{2} \mathrm{H}_{5}\right)_{2} \quad\left(\delta_{11_{\mathrm{B}}}=0 \mathrm{ppm}\right)$ and $\mathrm{C}_{6} \mathrm{H}_{5} \mathrm{CF}_{3}\left(\delta_{19_{\mathrm{F}}}=-63.72 \mathrm{ppm}\right)$, respectively. Heteronuclear $\mathrm{C}-\mathrm{H}$ correlations ( $\mathrm{HMBC}$ and HSQC) were used for the signal assignment. NMR spectra of the clathrochelate $\mathrm{FeBd}_{2}((\mathrm{PhenGm}))(\mathrm{BF})_{2}$ are not complete due to its low solubility. Given $J_{1_{\mathrm{H}-}{ }_{\mathrm{H}}}$ couplings are not exact values but only illustrate the shape of the observed multiplets.

\section{X-Ray Crystallography}

Intensity data for the complexes $\mathrm{FeBd}_{2}((\mathrm{Phn}) \mathrm{Gm})(\mathrm{BF})_{2} \cdot \mathrm{CHCl}_{3}$ and $\mathrm{FeBd}_{2}((\mathrm{Phen}) \mathrm{Gm})(\mathrm{BF})_{2} \cdot \mathrm{nCHCl}_{3}$ were collected on a Bruker Apex DUO CCD diffractometer equipped with a graphite-monochromated $\operatorname{MoK}_{\alpha}(\lambda=0.71073 \AA)$ radiation source at $150(2) \mathrm{K}$. The SMART software was used for data collection and also for indexing the reflections and determining the unit cell parameters; the collected data were integrated using SAINT software and corrected with SADABS ${ }^{[9]}$ for absorption. The structures were solved by the direct method ${ }^{[10]}$ and refined by full-matrix least-squares using SHELXTL software. ${ }^{[1]}$ All non-hydrogen atoms were refined in the anisotropic approximation. Chloroform molecules in the crystal $\mathrm{FeBd}_{2}((\mathrm{Phen}) \mathrm{Gm})(\mathrm{BF})_{2} \cdot \mathrm{n} \mathrm{CHCl}_{3}$ were found to be strongly disordered, and, therefore, SQUEEZE routine implemented in PLATON program complex, ${ }^{[12]}$ was applied for intensity data correction. Crystallographic data and refinement details are collected in Table 1. Structural data have been deposited to the Cambridge Structural Database (CCDC references 1508525 and 1508524) and are available free of charge at https://summary.ccdc.cam.ac.uk/ structure-summary-form.

\section{Synthesis}

$\mathrm{FeBd}_{2}(($ Phen $) \mathrm{Gm})(\mathrm{BF})_{2} . \quad \mathrm{FeBd}_{2}\left(\left(\mathrm{NH}_{2}\right)_{2} \mathrm{Gm}\right)(\mathrm{BF})_{2} \quad$ complex $(0.103 \mathrm{~g}, 0.15 \mathrm{mmol})$ and 1,10-phenanthroline-5,6-dione (0.318 g, $0.15 \mathrm{mmol}$ ) were dissolved/suspended in DMSO $(15 \mathrm{ml})$ and DBU was added $(0.4 \mathrm{ml})$. The reaction mixture was left for three weeks at r.t. and then was poured into brine. The precipitate formed was filtered off, dried in air and extracted with chloroform. The extract was chromatographically separated on silica gel (230-400 mesh, $1 \times 20 \mathrm{~cm}$ column, eluent: chloroform). The green product was collected, the solvent was evaporated to dryness and the solid residue was dried in vacuo. Yield: $0.100 \mathrm{~g}(75 \%)$. X-Ray quality single crystals of the complex $\mathrm{FeBd}_{2}((\mathrm{Phen}) \mathrm{Gm})(\mathrm{BF})_{2} \cdot \mathrm{n} \mathrm{CHCl}_{3}$, suitable for X-ray diffraction experiment, were obtained by recrystallization from chloroform-heptane 6:1 mixture. Found (\%): C 56.38; H 3.14; $\mathrm{N}$ 15.79; F 4.40; B 2.42. Calculated for $\mathrm{FeC}_{38} \mathrm{H}_{28} \mathrm{~N}_{8} \mathrm{O}_{6} \mathrm{~B}_{2} \mathrm{~F}_{2}$ (\%): C 57.18; H 2.97; N 15.88; F 4.31; B 2.45. ${ }^{1} \mathrm{H}$ NMR $\left(\mathrm{CDCl}_{3}\right) \delta$ ppm: 7.3 (m, 22H (Ph+Phen)), 8.09 (br.s, 2H), 9.54 (br.s, $2 \mathrm{H}) .{ }^{13} \mathrm{C}\left\{{ }^{1} \mathrm{H}\right\}$ NMR (DMSO) $\delta$ ppm: $128.19(\mathrm{~s}, o-\mathrm{Ph}), 128.62(\mathrm{~s}, i-\mathrm{Ph}), 129.88$, 130.826 (two s, $m-\mathrm{Ph}$ ), $130.93(\mathrm{~s}, p-\mathrm{Ph}), 133.81(\mathrm{~s}, \mathrm{NC}=\mathrm{N}), 157.1$

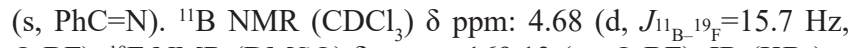
$\left.\mathrm{O}_{3} \mathrm{BF}\right) .{ }^{19} \mathrm{~F}$ NMR (DMSO) $\delta \mathrm{ppm}:-169.13\left(\mathrm{~m}, \mathrm{O}_{3} \mathrm{BF}\right)$. IR (KBr) $v$ $\mathrm{cm}^{-1}$ : 925, 983, 1001, 1031, 1074, 1120, $1160 v(\mathrm{~N}-\mathrm{O}), 1215 \mathrm{~m} v(\mathrm{~B}-$ $\mathrm{O})+v(\mathrm{~B}-\mathrm{F}), 1554 v(\mathrm{NC}=\mathrm{N}), 1579 v(\mathrm{PhC}=\mathrm{N}) . \mathrm{UV}-\mathrm{Vis}\left(\mathrm{CHCl}_{3}\right) \lambda$ $\left(\varepsilon \cdot 10^{-3}\right) \mathrm{nm}: 260(32), 310(23), 430(13), 600(14), 640(14)$.

$\mathrm{FeBd}_{2}((\mathrm{Phn}) \mathrm{Gm})(\mathrm{BF})_{2}$. This complex was obtained similar to $\left.\mathrm{FeBd}_{2(}(\mathrm{Phen}) \mathrm{Gm}\right)(\mathrm{BF})_{2}$ except $\left.\mathrm{Fe}(\mathrm{Bd})_{2}\left(\mathrm{NH}_{2}\right)_{2} \mathrm{Gm}\right)(\mathrm{BF})_{2}(0.112 \mathrm{~g}$, $0.16 \mathrm{mmol})$, phenanthrene-9,10-dione $(0.343 \mathrm{~g}, 0.17 \mathrm{mmol})$ and DBU $(0.3 \mathrm{ml})$ were used. Yield: $0.110 \mathrm{~g}(80 \%)$. X-Ray quality single crystals of the complex $\mathrm{FeBd}_{2}(\mathrm{Phn}) \mathrm{Gm}(\mathrm{BF})_{2} \mathrm{CHCl}_{3}$ were obtained by recrystallization from chloroform-heptane $6: 1 \mathrm{v} / \mathrm{v}$ mixture.

Table 1. Crystal data and structure refinement for the iron(II) clathrochelates $\mathrm{FeBd}_{2}((\mathrm{Phn}) \mathrm{Gm})(\mathrm{BF})_{2}$ and $\mathrm{FeBd}((\mathrm{Phen}) \mathrm{Gm})(\mathrm{BF})_{2}$.

\begin{tabular}{|c|c|c|}
\hline Parameter & $\mathrm{FeBd}_{2}((\mathrm{Phn}) \mathrm{Gm})(\mathrm{BF})_{2}$ & $\mathrm{FeBd}_{2}((\mathrm{Phen}) \mathrm{Gm})(\mathrm{BF})_{2}$ \\
\hline Empirical formula & $\mathrm{C}_{45} \mathrm{H}_{29} \mathrm{~B}_{2} \mathrm{Cl}_{3} \mathrm{~F}_{2} \mathrm{FeN}_{8} \mathrm{O}_{6}$ & $\mathrm{C}_{42} \mathrm{H}_{26} \mathrm{~B}_{2} \mathrm{~F}_{2} \mathrm{FeN}_{10} \mathrm{O}_{6}$ \\
\hline Formula weight & 999.58 & 882.20 \\
\hline Crystal system & Triclinic & Triclinic \\
\hline Space group & $\mathrm{P} \overline{1}$ & $\mathrm{P} \overline{1}$ \\
\hline$a(\AA)$ & $12.0320(7)$ & $12.0729(14)$ \\
\hline$b(\AA)$ & $13.2629(7)$ & $12.8651(13)$ \\
\hline$c(\AA)$ & $13.6241(8)$ & $13.6088(16)$ \\
\hline$\alpha\left(^{\circ}\right)$ & $91.155(2)$ & $90.325(4)$ \\
\hline$\beta\left(^{\circ}\right)$ & $94.026(2)$ & $92.576(4)$ \\
\hline$\gamma\left({ }^{\circ}\right)$ & $99.730(2)$ & $100.636(3)$ \\
\hline $\mathrm{V}\left(\AA^{3}\right)$ & $2136.4(2)$ & 2075.1(4) \\
\hline Z & 2 & 2 \\
\hline$D_{x}\left(g / \mathrm{cm}^{3}\right)$ & 1.554 & 1.412 \\
\hline$\mu\left(\mathrm{mm}^{-1}\right)$ & 0.611 & 0.433 \\
\hline Crystal size $\left(\mathrm{mm}^{3}\right)$ & $0.36 \times 0.26 \times 0.18$ & $0.20 \times 0.11 \times 0.05$ \\
\hline$\Theta$ range $\left(^{\circ}\right)$ & $1.56-27.67$ & $1.50-26.37$ \\
\hline Reflections collected & 17056 & 16775 \\
\hline Independent reflections $\left(R_{\text {int }}\right)$ & $9772\left(R_{\mathrm{int}}=0.0144\right)$ & $8438\left(R_{\mathrm{int}}=0.0281\right)$ \\
\hline Max. and min. transmission & 0.896 and 0.826 & 0.979 and 0.944 \\
\hline Goodness-of-fit on $F^{2}$ & 0.839 & 1.051 \\
\hline Final $R$ indices $[I>2 \delta(\mathrm{I})]$ & $R_{1}=0.0504, \mathrm{w} R_{2}=0.1395$ & $R_{1}=0.0405, \mathrm{w} R_{2}=0.0908$ \\
\hline$R$ indices (all data) & $R_{1}=0.0570, \mathrm{w} R_{2}=0.1434$ & $R_{1}=0.0574, \mathrm{w} R_{2}=0.0954$ \\
\hline Largest diff. peak and hole $\left(\mathrm{e} / \AA^{3}\right)$ & 0.895 and -1.690 & 0.377 and -0.358 \\
\hline
\end{tabular}


Found (\%): C 59.92; H 3.30; N 12.66; B 2.42; F 4.27. Calculated for $\mathrm{FeC}_{40} \mathrm{H}_{30} \mathrm{~N}_{6} \mathrm{O}_{6} \mathrm{~B}_{2} \mathrm{~F}_{2}(\%)$ : $\mathrm{C} 60.04 ; \mathrm{H} 3.21 ; \mathrm{N} 12.73$; B 2.46; $\mathrm{F}$ 4.32. ${ }^{1} \mathrm{H}$ NMR $\left(\mathrm{CDCl}_{3}\right) \delta \mathrm{ppm}: 7.28(\mathrm{~d}, 8 \mathrm{H}, o-\mathrm{Ph}), 7.34(\mathrm{~m}, 12 \mathrm{H}$ $(m-\mathrm{Ph}+p-\mathrm{Ph}), 7.63\left(\mathrm{td}, 2 \mathrm{H}, J_{l}=7.6 \mathrm{~Hz}, J_{2}=0.9 \mathrm{~Hz}(\mathrm{H}-8+\mathrm{H}-15)\right), 7.79$ $(\mathrm{td}, 2 \mathrm{H}, J=7.6 \mathrm{~Hz}, J=1.2 \mathrm{~Hz}(\mathrm{H}-9+\mathrm{H}-14)), 8.36$ (br.d, $2 \mathrm{H}, J=8.0 \mathrm{~Hz}$ $(\mathrm{H}-10+\mathrm{H}-13)), 9.23\left(\mathrm{dd}, 2 \mathrm{H}, J_{1}=8.0 \mathrm{~Hz}, J_{2}=1.2 \mathrm{~Hz}(\mathrm{H}-7+\mathrm{H}-16)\right)$. ${ }^{13} \mathrm{C}$ NMR (DMSO, carbon labeling is given in the Scheme 3 ) $\delta$ ppm: 123.58 (br.s (C-10+C-13)), 128.10 (s, o-Ph), 128.65 (br.s (C-7+C-16)), 128.83 (s, $i$-Ph), 128.89 (br.s (C-8+C-15)), 129.72 (br.s (C-6+C-17)), 130.66 (s, $p$-Ph), 130.86 (s, $m$-Ph), 132.98 (br.s (C-9 + C-14)), 133.64 (br.s (C-11+C-12)), 146.13 (br.s (C-2+C-3)), 147.47 (br.s $(\mathrm{C}-5+\mathrm{C}-18)), 156.7(\mathrm{~s}, \mathrm{PhC}=\mathrm{N}) .{ }^{11} \mathrm{~B} \mathrm{NMR}\left(\mathrm{CDCl}_{3}\right) \delta$ ppm: 4.61 (d, $\left.J_{11}{ }_{\mathrm{B}-1}{ }^{19}{ }_{\mathrm{F}}=17.2 \mathrm{~Hz}, \mathrm{O}_{3} \mathrm{BF}\right) .{ }^{19} \mathrm{~F} \mathrm{NMR}(470 \mathrm{MHz}, \mathrm{DMSO})$ $\delta$ ppm: -169.17 (m, O 3 BF). IR (KBr) $v \mathrm{~cm}^{-1}$ : 920, 989, 1000, 1047, $1072,1118,1161 v(\mathrm{~N}-\mathrm{O}), 1216 \mathrm{~m} v(\mathrm{~B}-\mathrm{O})+v(\mathrm{~B}-\mathrm{F}), 1549 v(\mathrm{NC}=\mathrm{N})$, $1581 v(\mathrm{PhC}=\mathrm{N})$. UV-Vis $\left(\mathrm{CHCl}_{3}\right) \lambda\left(\varepsilon \cdot 10^{-3}\right) \mathrm{nm}: 253(53), 320(17)$, 440(17), 607(25), 645(24).<smiles>CN1CN(C)c2nc3c4cccnc4c4ncccc4c3nc21</smiles>

Scheme 3.

\section{Cyclic Voltammetry}

Cyclic voltammetry (CV) was performed using a Metrohm 797 VA Computrace instrument with a glassy carbon (GC) and platinum working electrodes and a saturated $\mathrm{Ag} / \mathrm{AgCl}$ in $3.5 \mathrm{M}$ $\mathrm{KCl}$ as a reference electrode. Tetra- $n$-butylammonium perchlorate in chloroform $(0.1 \mathrm{M})$ was used as the supporting electrolyte. Solutions of the samples in the electrolyte (1-2 mM) were degassed by purging with argon prior to the $\mathrm{CV}$ measurements.

\section{Results and Discussion}

Condensation of $\mathrm{FeBd}_{2}\left(\left(\mathrm{NH}_{2}\right)_{2} \mathrm{Gm}\right)(\mathrm{BF})_{2} \quad$ with 1,10-phenanthroline-5,6-dione or phenanthrene-9,10-dione in the presence of 1,8-diazabicyclo[5.4.0]undecene-7 (DBU) as a strong organic base in aprotic polar DMSO media afforded the target macrobicyclic complexes $\mathrm{FeBd}_{2}((\mathrm{Phen})$ $\mathrm{Gm})(\mathrm{BF})_{2}$, the derivative of phenanthroline, and $\mathrm{FeBd}_{2}((\mathrm{Phn})$ $\mathrm{Gm})(\mathrm{BF})_{2}$, the derivative of phenanthrene, in high yields (Scheme 4).

These reactions proceeded via electrophilic attack of the corresponding dicarbonyl component (i.e. phenanthrolinedione or phenanthrenedione) at the deprotonated amino groups of the macrobicyclic precursor followed by elimination of water molecules. In the course of this addition elimination reaction, the initial red reaction mixture changed color to grayish-crimson thus allowing its naked-eye control.

The single crystal X-ray structures of the clathrochelate products $\mathrm{FeBd}_{2}((\mathrm{Phen}) \mathrm{Gm})(\mathrm{BF})_{2}$ and $\mathrm{FeBd}_{2}((\mathrm{Phn}) \mathrm{Gm})(\mathrm{BF})_{2}$ are shown in Figure 1. They confirmed that the reaction of $\mathrm{FeBd}_{2}\left(\left(\mathrm{NH}_{2}\right)_{2} \mathrm{Gm}\right)(\mathrm{BF})_{2}$ with the above $o$-quinones gave the target clathrochelates with annulated 1,4,8,9-tetraazatriphenylene or 1,4-diazatriphenylene fragment. The intermediate trigonal prismatic (TP) - trigonal antiprismatic (TAP) geometry of their cage frameworks is only slightly affected by the formation of these annulated fragments. The heights of both TP-TAP $\mathrm{FeN}_{6}$-coordination polyhedra is approximately $2.37 \AA$; their distortion angles $\varphi$ are equal to $21.6^{\circ}$ and $23.4^{\circ}$, respectively $\left(\varphi=0^{\circ}\right.$ for an ideal TP, $\varphi=60^{\circ}$ for an ideal TAP). Fe-N distances fall in a narrow range 1.90-1.94 $\AA$ for both these cage complexes. The terminal phenanthroline fragment of the annulated tetraazatriphenylene heterocyclic substituent of $\mathrm{FeBd}_{2}((\mathrm{Phen}) \mathrm{Gm})(\mathrm{BF})_{2}$ is structurally quite similar to 1,4,8,9-tetraazatriphenylene-2,3-dicarbonitrile. ${ }^{[13]}$ On the other hand, the pyrazine fragment of the molecule $\mathrm{FeBd}_{2}((\mathrm{Phen}) \mathrm{Gm})(\mathrm{BF})_{2}$ has some touch of quinoid alternation with $\mathrm{C}_{\text {clat }}-\mathrm{N}$ bond lengths close to $1.35 \AA$ and $\mathrm{N}-\mathrm{C}_{\text {het }}$ distances of approximately $1.32 \AA$. Similarly, the carbocyclic (phenanthrene) part of $\mathrm{FeBd}_{2}(\mathrm{Phn}) \mathrm{Gm}(\mathrm{BF})_{2}$ was found to be structurally very similar to 2,3-dicyanodibenzo(f,h) quinoxaline; ${ }^{[14]}$ its pyrazine moiety also has a quinoid character and the same $\mathrm{C}_{\text {clat }}-\mathrm{N}$ and $\mathrm{N}-\mathrm{C}_{\text {carb }}$ bond lengths of $1.35 \AA$ and $1.32 \AA$, respectively.

The crystals of these cage complexes contain the clathrochelate dimers formed via stacking interactions shown in Figure 2.

In the $\mathrm{FeBd}_{2}((\mathrm{Phen}) \mathrm{Gm})(\mathrm{BF})_{2}$ crystal, the heterocyclic fragments of their macrobicyclic entities are almost parallel. These macrobicyclic molecules are related by the

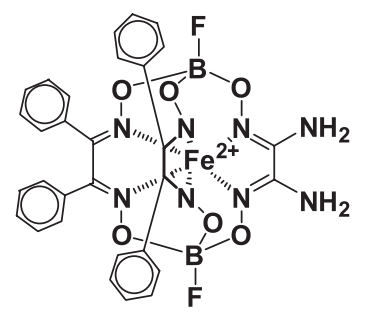

$\mathrm{FeBd}_{2}\left(\left(\mathrm{NH}_{2}\right)_{2} \mathrm{Gm}\right)(\mathrm{BF})_{2}$

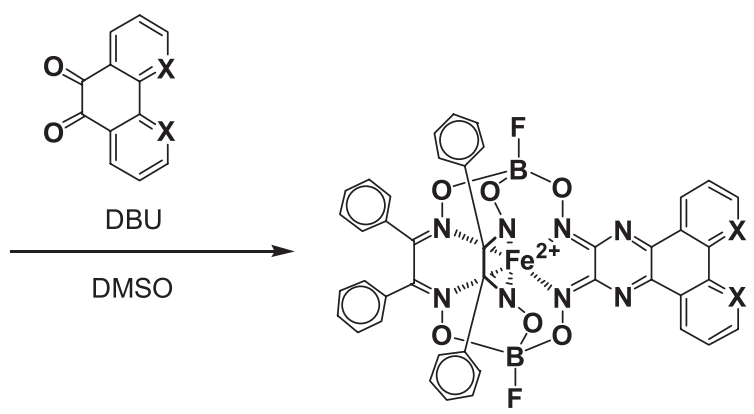

$\mathrm{FeBd}_{2}($ Phen $\left.) \mathrm{Gm}\right)(\mathrm{BF})_{2} \quad \mathrm{X}=\mathrm{N}$ $\left.\mathrm{FeBd}_{2}(\mathrm{Phn}) \mathrm{Gm}\right)(\mathrm{BF})_{2} \mathrm{X}=\mathrm{CH}$

Scheme 4. 

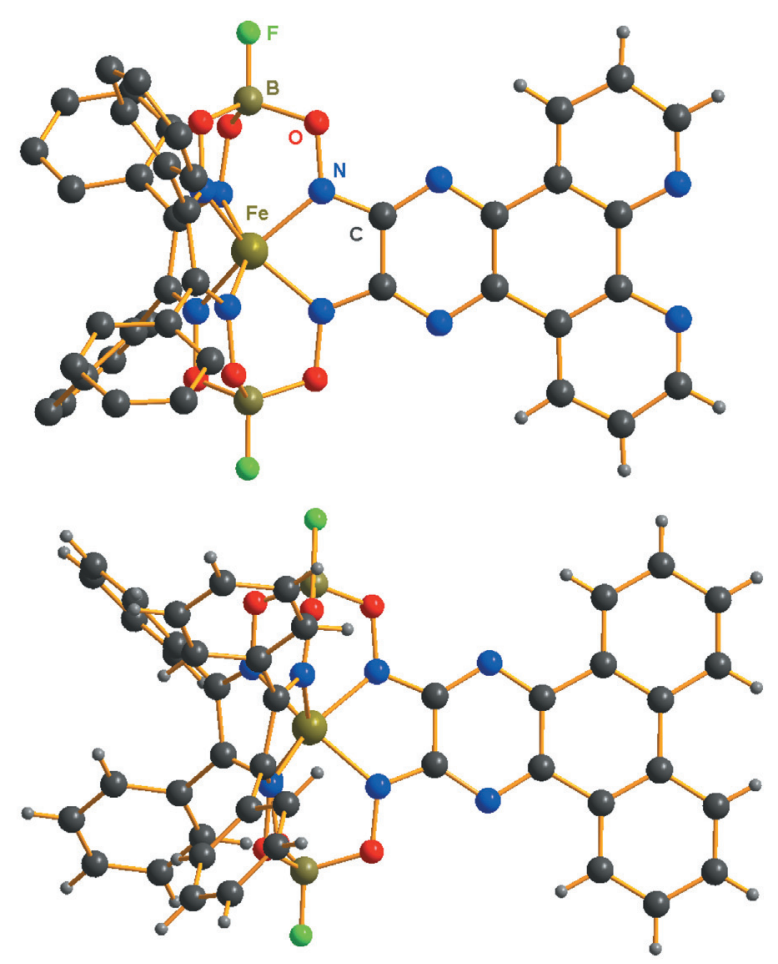

Figure 1. General views of the clathrochelates $\mathrm{FeBd}_{2}(\mathrm{Phen})$ $\mathrm{Gm}(\mathrm{BF})_{2}$ (top) and $\mathrm{FeBd}_{2}(\mathrm{Phn}) \mathrm{Gm}(\mathrm{BF})_{2}$ (bottom).
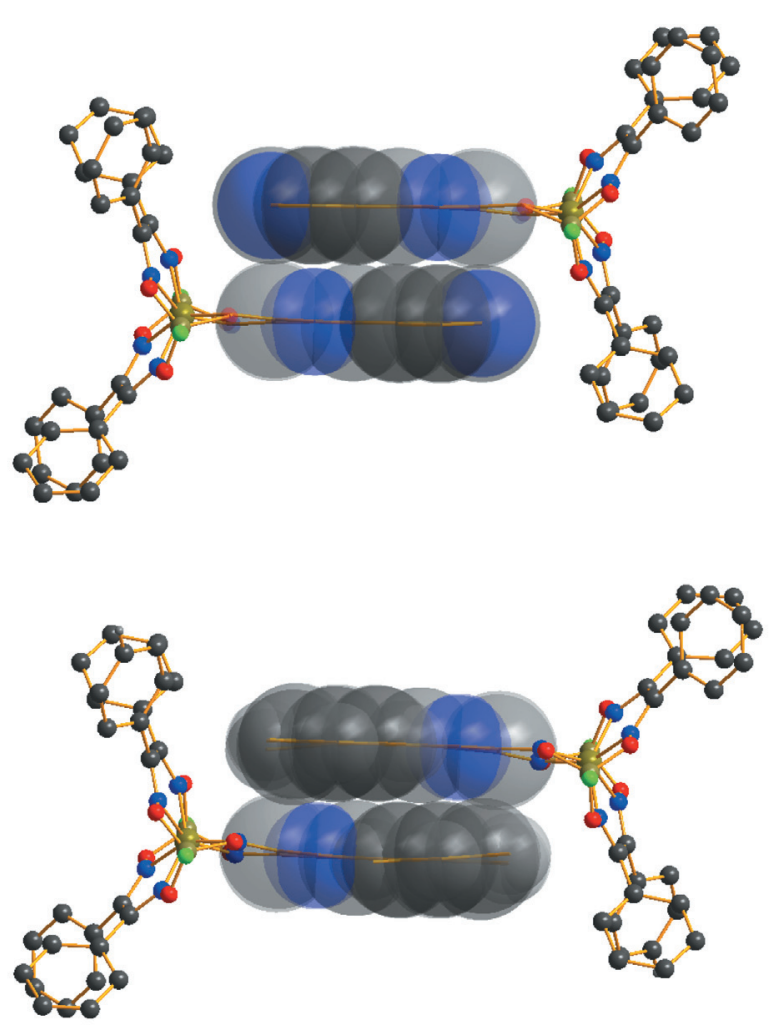

Figure 2. Side view of the clathrochelate dimers formed by the complexes FeBd $((\mathrm{Phen}) \mathrm{Gm})(\mathrm{BF})_{2}$ (top) and $\mathrm{FeBd}_{2}((\mathrm{Phn})$ $\mathrm{Gm})(\mathrm{BF})_{2}$ (bottom). Semi-transparent spheres denote van der Waals radii of the non-hydrogen atoms of their annulated ribbed fragments. Hydrogen atoms are omitted for clarity.
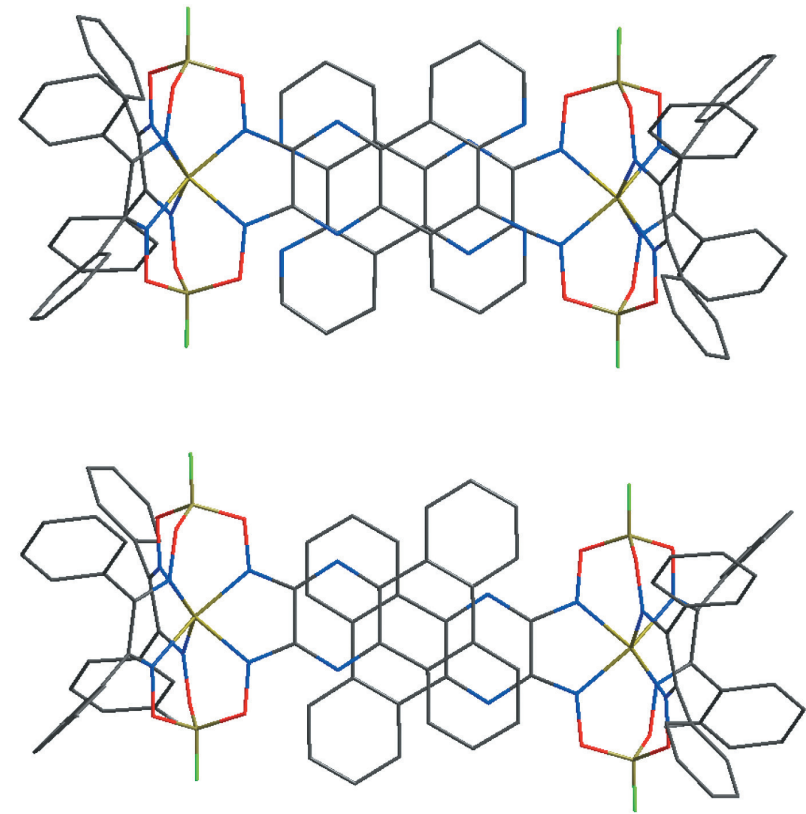

Figure 3. Perpendicular views of the clathrochelate dimers, formed by the cage complexes $\mathrm{FeBd}_{2}((\mathrm{Phen}) \mathrm{Gm})(\mathrm{BF})_{2}$ (top) and $\mathrm{FeBd}_{2}((\mathrm{Phn}) \mathrm{Gm})(\mathrm{BF})_{2}$ (bottom). Hydrogen atoms are omitted for clarity.

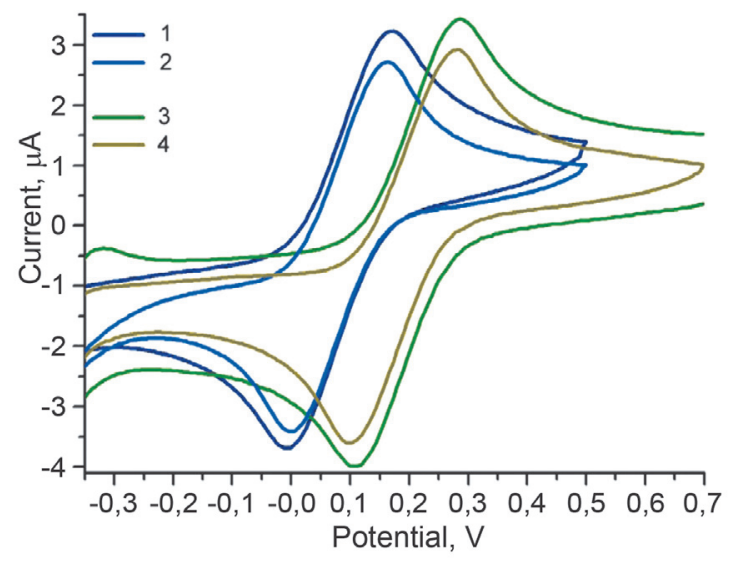

Figure 4. $\mathrm{CV}$ of the chloroform solutions of $\mathrm{FeBd}_{2}((\mathrm{Phn}) \mathrm{Gm})$ $(\mathrm{BF})_{2}(1 \mathrm{GC}, 2 \mathrm{Pt})$ and $\mathrm{FeBd}_{2}((\mathrm{Phen}) \mathrm{Gm})(\mathrm{BF})_{2}(3 \mathrm{GC}, 4 \mathrm{Pt})$ at scan rate $50 \mathrm{mV} \cdot \mathrm{s}^{-1}$.

crystallographic inversion center; the deviations of their atoms from the corresponding mean plane do not exceed $0.0025 \AA$. The distance between the mean planes of these interacting fragments is approximately $3.34 \AA$. In the crystal of the $\mathrm{FeBd}_{2}((\mathrm{Phn}) \mathrm{Gm})(\mathrm{BF})_{2}$ complex, its annulated fragment is more distorted with the deviations reaching $0.1 \AA$, and the distance between the above mean planes in its clathrochelate dimer being even slightly smaller (3.32 $\AA$ ); overlapping between the heterocyclic fragments of the corresponding macrobicyclic entities is shown in Figure 3. Such a short interplane separation and rather small slippage (the distances between the centroids of their annulated 


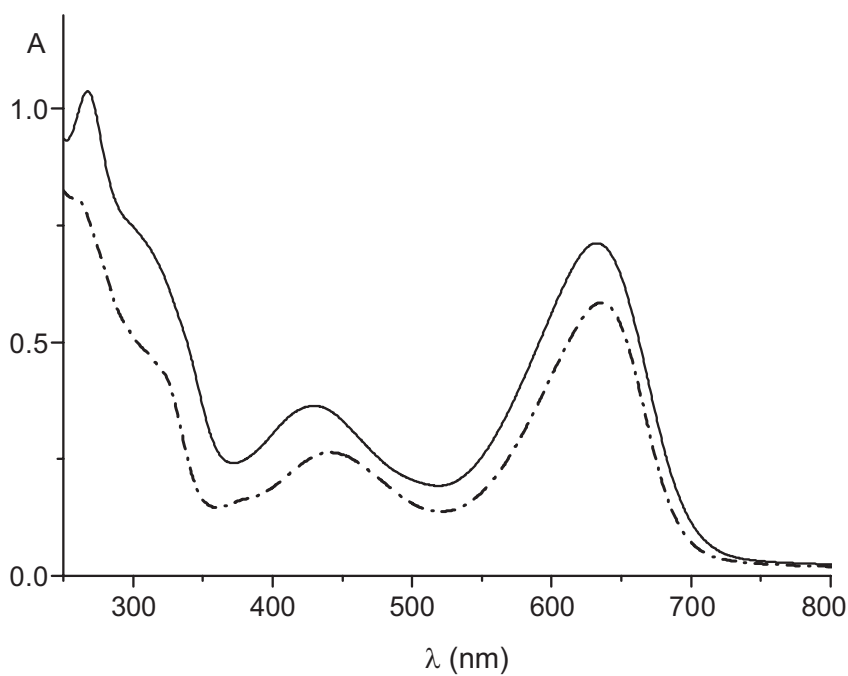

Figure 5. UV-Vis spectra of chloroform solutions of the cage complexes $\mathrm{FeBd}_{2}(\mathrm{Phen}) \mathrm{Gm}(\mathrm{BF})_{2}$ (solid) and $\mathrm{FeBd}_{2}(\mathrm{Phn}) \mathrm{Gm}(\mathrm{BF})_{2}$ (dash dot).

heterocyclic systems fall in the range 3.5-3.6 ̊) results in the substantial overlapping causing a strong stabilization of these supramolecular assemblies. Theoretical estimations of dimerization energy for triphenylene (approximately $10 \mathrm{kcal} / \mathrm{mol}^{[15]}$ ) suggest the same order of magnitude for that of the above clathrochelate dimers.

Such dimerization may be a reason of the observed poor solubility of these cage complexes in most common organic solvents estimated to be in the range $10^{-6}-10^{-}$ ${ }_{5}^{5} \mathrm{~mol} / \mathrm{L}$, while the typical values for other cage iron(II) tris-dioximates of this type are higher by approximately two orders of magnitude. Only in the case of chloroform as a solvent, the solubility of the clathrochelates obtained approaches to $10^{-3} \mathrm{~mol} / \mathrm{L}$.

CVs of $\mathrm{FeBd}_{2}((\mathrm{Phn}) \mathrm{Gm})(\mathrm{BF})_{2}$ and $\mathrm{FeBd}_{2}((\mathrm{Phen}) \mathrm{Gm})$ $(\mathrm{BF})_{2}$ (Figure 4) show one reduction wave with $E_{1 / 2}$ of $70 \mathrm{mV}$ and $190 \mathrm{mV}$, respectively. The CV curves registered on Pt and GC are practically identical in shape and position. The symmetric shapes of this curves and the little drift of the peak potentials with scan rate (within $50-250 \mathrm{mV} \cdot \mathrm{s}^{-1}$ ) suggest the equilibrium character of these electrochemical redox processes.

The green-bluish color of chloroform solutions of the clathrochelates $\mathrm{FeBd}_{2}((\mathrm{Phen}) \mathrm{Gm})(\mathrm{BF})_{2}$ and $\mathrm{FeBd}_{2}((\mathrm{Phn})$ $\mathrm{Gm})(\mathrm{BF})_{2}$ is caused by the presence of more intensive band with the maximum at approximately $635 \mathrm{~nm}$ (for both of these complexes) and less intensive band with maxima at approximately 430 and $440 \mathrm{~nm}$, respectively, in their UVVis spectra (Figure 5).

We also succeeded in the registration of UV-Vis spectrum of the solution of $\mathrm{FeBd}_{2}(\mathrm{Phen}) \mathrm{Gm}(\mathrm{BF})_{2}$ in electrochemically inert acetonitrile; its poor solubility in this solvent was compensated both by high molar extinction coefficient of this cage complex and by long optical path (10 cm cuvette). The initial UV-Vis spectrum of the clathrochelate $\mathrm{FeBd}_{2}((\mathrm{Phen}) \mathrm{Gm})(\mathrm{BF})_{2}$ and its changes during reduction of this cage complex with metallic lithium are

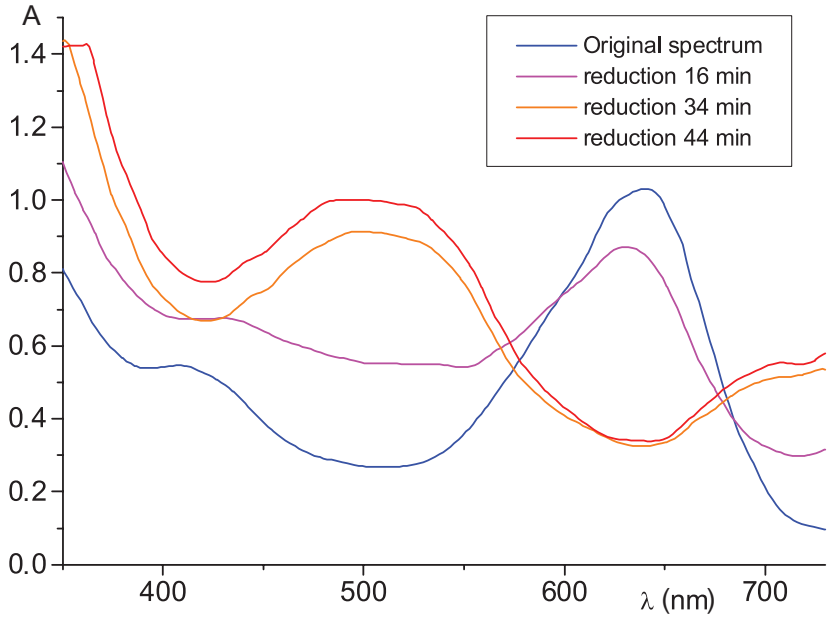

Figure 6. Changes in the UV-Vis spectrum of the acetonitrile solution of the clathrochelate $\mathrm{FeBd}_{2}((\mathrm{Phen}) \mathrm{Gm})(\mathrm{BF})_{2}$ in the course of its reduction with metallic lithium $\left(C_{\text {clat }}<10^{-5} \mathrm{M}, l=10 \mathrm{~cm}\right)$.

shown in Figure 6. The green-bluish color of this acetonitrile solution is determined by two broad bands with maxima at approximately 410 and $640 \mathrm{~nm}$. The above reduction caused the appearance of new band at approximately $500 \mathrm{~nm}$ and the disappearance of the absorption bands of the initial cage complex. So, the reduction resulted in the formation of the red solution. The absence of proper isosbestic points can be explained by the low concentration of the initial complex comparable with that of the trace contaminants remaining in the solvent. The spectrum of the reduced macrobicyclic derivative of $\left.\mathrm{FeBd}_{2}((\mathrm{Phen})) \mathrm{Gm}\right)(\mathrm{BF})_{2}$ is quite similar to that of the anion-radical derivative of the quinoxaline-containing clathrochelate analog, ${ }^{[5]}$ thus suggesting chemical one-electron ligand-centered reduction of $\mathrm{FeBd}_{2}((\mathrm{Phen}) \mathrm{Gm})(\mathrm{BF})_{2}$.

The solubility of $\mathrm{FeBd}_{2}((\mathrm{Phn}) \mathrm{Gm})(\mathrm{BF})_{2}$ in acetonitrile was found to be even lower than that of $\mathrm{FeBd}_{2}((\mathrm{Phen}) \mathrm{Gm})$ $(\mathrm{BF})_{2}$, and we were unable to register its UV-Vis spectrum in proper quality.

\section{Conclusions}

Thus, we have demonstrated that electrophilic addition can be successfully used for preparation of the iron(II) tris-dioximate clathrochelates bearing extended redoxactive annulated ribbed substituents. The study of donor properties of the phenanthroline-terminated clathrochelate $\mathrm{FeBd}_{2}((\mathrm{Phen}) \mathrm{Gm})(\mathrm{BF})_{2}$ as a potent chelating macrobicyclic ligand is in progress in our group.

Acknowledgements. This study was partly supported by RFBR (grants 16-03-00408 and 15-03-07509). Y.Z.V. also thanks the Russian Science Foundation (project 16-1310475) for the financial support of the synthetic part of this work. The authors are indebted to Mr. I. Novozhilov (NIIC SB RAS) for performing CV measurements. 
Electrophilic Addition of Polyaromatic o-Quinones to an Iron(II) Diaminoclathrochelate

\section{References}

1. Viswanathan S., Voloshin Y.Z., Radecka H., Radecki J. Electrochimica Acta 2009, 54(23), 5431-5438.

2. Liu W., Huang W., Pink M., Lee D. J. Am. Chem. Soc. 2010, $132,11844-11846$.

3. Liu W., Huang W., Chen C.-H., Pink M., Lee D. Chem. Mater. 2012, 24, 3650-3658.

4. Sabin J.R., Varzatskii O.A., Voloshin Y.Z., Starikova Z.A., Novikov V.V., Nemykin V.N. Inorg. Chem. 2012, 51, 8362-8372.

5. Burdukov A.B., Vershinin M.A., Pervukhina N.V., Boguslavsky E.G., Eltsov I.V., Shundrin L.A., Selector S.L., Shokurov A.V., Voloshin Y.Z. Inorg. Chem. Commun. 2014, 44, 183-187.

6. Burdukov A.B., Šipoš R., Vershinin M.A., Pervukhina N.V., Kuratieva N.V., Plyusnin P.E., Eltsov I.V., Voloshin Y.Z. J. Coord. Chem. 2015, 68, 3894-3902.

7. Vershinin M.A., Burdukov A.B., Boguslavskii E.G., Pervukhina N.V., Kuratieva N.V., Eltsov I.V., Reznikov V.A.,
Varzatskii O.A., Voloshin Y.Z., Bubnov Y.N. Inorg. Chim. Acta 2011, 366, 91-97.

8. Armarego W.L.F., Chai C. Purification of Laboratory Chemicals, 6 ed., Oxford: Butterworth-Heinemann, 2009. 609 p.

9. Bruker AXS Inc., APEX2 (Version 1.08), SAINT (Version 7.03), and SADABS (Version 2.11). Bruker Advanced X-ray Solutions, Madison, Wisconsin, USA (2004).

10. Burla M.C., Caliandro R., Camall M., Carrozzini B., Cascarano G.L., De Caro L., Giacovazzo C., Polidori G., Spagna R. J. Appl. Cryst. 2005, 38, 381-388.

11. Sheldrick G.M. SHELX97 Release 97-2, University of Gottingen, Germany, 1998.

12. http://www.chem.gla.ac.uk/ louis/software/platon/

13. Yang W., Qiu Q.-M., Zhou L.-L., Jin Q.-H., Zhang C.-L. Acta Crystallogr., Sect. E: Struct. Rep. Online 2011, 67, o3250.

14. Nishida J., Murai S., Fujiwara E., Tada H., Tomura M., Yamashita Y. Org. Lett. 2004, 6, 2007-2010.

15. Cinacchi G., Prampolini G. J. Phys. Chem. C 2008, 112, 95019509. 